\title{
Relationship between high-mobility group box I overexpression in ovarian cancer tissue and serum: a meta-analysis
}

This article was published in the following Dove Press journal:

OncoTargets and Therapy

27 November 2015

Number of times this article has been viewed

\author{
Haipeng Wang ${ }^{1,2}$ \\ Zengjun $\mathrm{Li}^{2}$ \\ Yanlai Sun ${ }^{2}$ \\ Zhongfa $\mathrm{Xu}^{2}$ \\ Jianjun $\mathrm{Han}^{2}$ \\ Bao Song ${ }^{3}$ \\ Wentao Song ${ }^{1,2}$ \\ Chen Qin ${ }^{1,2}$ \\ Lei Yin ${ }^{1,2}$
}

'Department of Surgery, Shandong Academy of Medical Sciences, University of Jinan, Jinan, Shandong, People's Republic of China; ${ }^{2}$ Department of General Surgery, Shandong Cancer Hospital and Institute, Shandong Academy of Medical Sciences, University of Jinan, Jinan, Shandong, People's Republic of China; ${ }^{3}$ Cancer Research Center, Shandong Provincial Key Laboratory of Oncology, Shandong Cancer Hospital and Institute, Shandong Academy of Medical Sciences, University of Jinan, Jinan, Shandong, People's Republic of China
Correspondence: Zengjun Li Department of General Surgery, Shandong Cancer Hospital and Institute, Shandong Academy of Medical Sciences, University of Jinan, 440 Jiyan Road, Jinan 2501 17, Shandong, People's Republic of China

Tel +86531 67626245

Email lizengjun6@hotmail.com
Objective: To implement a meta-analysis to investigate the relationship between high-mobility group box 1 (HMGB1) overexpression in the tissue and serum of ovarian cancer patients, and to evaluate its prognostic significance.

Methods: Searches were made of China National Knowledge Infrastructure, EMBASE, WanFang, PubMed, MEDLINE, and Web of Science databases up to August 2015, with no language or style restrictions. Reference lists of related studies were also carefully reviewed to identify additional articles.

Results: The literature search identified a total of 12 relevant studies on HMGB1 expression for inclusion in the meta-analysis: seven in ovarian tumor tissue, four in ovarian tumor patient serum, and one in both tissue and serum. HMGB1 protein levels in ovarian cancer tissues were notably higher than those in normal ovarian tissues with no evidence of heterogeneity between studies ( $\mathrm{RD}=0.64,95 \%$ confidence interval $(\mathrm{CI})$ : $0.57-0.70, Z=18.70, P<0.00001, I^{2}=15 \%$ ), and also higher than those in benign tumor tissues with no evidence of heterogeneity between studies ( $\mathrm{RD}=0.52,95 \% \mathrm{CI}$ : $\left.0.43-0.61, Z=11.14, P<0.00001, I^{2}=0\right)$. Serum HMGB1 levels were similarly significantly higher in ovarian cancer patients than those with benign tumors or normal ovaries. Pooled mean differences of HMGB1 in ovarian cancer patients compared with patients with benign tumors or normal ovaries were 99.32 with $95 \%$ CI: $67.82-130.81$, $Z=6.18, P<0.00001$, and 95.34 with $95 \% \mathrm{CI}: 62.11-128.57, Z=5.62, P<0.0001$. The pooled relative risk of ovarian cancer with high vs low HMGB1 expression levels was 1.40 with $95 \%$ CI: $1.09-1.79, Z=2.66, P=0.008$, heterogeneity $I^{2}=50 \%$.

Conclusion: This meta-analysis suggested that HMGB1 levels in both tissue and serum of ovarian cancer patients were significantly higher than those of benign tumor and normal ovarian samples. High serum or tissue HMGB1 expression may therefore be an effective molecular marker for ovarian benign or malignant tumor diagnosis and patient prognosis.

Keywords: high-mobility group box 1, HMGB1, ovarian cancer, meta-analysis, prognosis, tissue, serum

\section{Introduction}

Ovarian cancer has the highest mortality rate of six lethal gynecologic malignancies, and demonstrates rapid disease progression. ${ }^{1-3}$ Although progress has been made in ovarian cancer research, ${ }^{4}$ survival and cure rates remain low. ${ }^{5}$ Because its occurrence may go unnoticed through a lack of typical symptoms and limited early diagnostic methods, women are often diagnosed with advanced disease when they seek medical advice. Indeed, $75 \%$ of patients present with advanced (stage III or IV) cancer, and although more than $80 \%$ of these benefit from first-line therapy, tumor recurrences occur in almost all patients in a median time of 15 months from diagnosis. ${ }^{2}$ 
Basic treatment for ovarian cancer involves traditional radical surgery with adjuvant chemotherapy, although new choices offered for middle-late ovarian cancer treatment include neoadjuvant chemotherapy, radiation therapy, biological therapy, immune therapy, and molecular target therapy. Ovarian cancer is heterogeneous, with each subtype associated with different genetic mutations, which can be used to predict the effect of targeted therapy. However, because tumor recurrence and metastasis are considered the main reasons for poor clinical outcome and morbidity, ${ }^{6}$ the identification of a protein that can be used to distinguish benign and malignant tumors would be beneficial in predicting patient prognosis. Moreover, studying the mechanism of tumor invasion and metastasis will provide further insights into the development and progression of ovarian cancer.

High-mobility group box 1 (HMGB1) was first identified in calf thymus as a highly conserved, nonchromosomal DNAbinding chromatin protein involved in DNA organization and the regulation of transcription. ${ }^{7,8}$ HMGB1 supports the transcription of many genes in its interaction with nucleosomes, transcription factors, and histones ${ }^{9}$ by inducing changes in nucleosome structure. ${ }^{10}$ Current research shows that HMGB1 plays a crucial role in Alzheimer's disease, ${ }^{11}$ arthritis, ${ }^{12}$ cardiovascular disease, ${ }^{13}$ inflammation, ${ }^{14}$ and sepsis. ${ }^{15}$ Moreover, it is significantly overexpressed in some cancers, including those of the bowel, ${ }^{16-18}$ pancreas, ${ }^{19}$ papillary thyroid ${ }^{20}$ lung, ${ }^{21}$ liver, ${ }^{22,23}$ cervix, ${ }^{24}$ stomach, ${ }^{25}$ and osteosarcoma. ${ }^{26}$ Some studies also reported higher HMGB1 expression in ovarian cancer compared with normal ovarian tissues or those with benign cysts. ${ }^{27-35}$ Similarly, higher HMGB1 expression has been observed in the serum of ovarian cancer patients compared with control individuals or those with benign tumors. Such high HMGB1 expression was found to be associated with poor prognosis, ${ }^{36-39}$ so HMGB1 has been proposed as a potential biomarker for ovarian cancer. In the present meta-analysis, we identified studies that described HMGB1 expression in ovarian cancer, benign ovarian tumors, and normal ovaries and evaluated the association between tissue and serum HMGB1 overexpression with ovarian cancer.

\section{Methods}

\section{Search strategy}

We performed a literature search of the following databases for articles published up to August 2015: China National Knowledge Infrastructure, WanFang, Web of Science, PubMed, MEDLINE, and EMBASE. No language restrictions were placed on the search, and the following search terms were used: "HMGB1 Protein" or "HMGB1" or "HMG1
Protein" or "HMG1" or "high-mobility group box 1" or "high-mobility group box protein 1" and "ovarian cancer" or "ovarian carcinoma" or "ovarian tumor". Additional relevant studies were identified from the reference lists of all selected original and review articles. The medical subject heading, methods, patient population, design, and outcome of these articles were used to identify relevant studies.

\section{Eligibility criteria}

Studies were included in the meta-analysis if they met the following criteria: 1) evaluated the association between HMGB1 overexpression in tissue and serum with ovarian cancer; 2) evaluated the association between HMGB1 overexpression and ovarian cancer prognosis; 3) used enzymelinked immunosorbent assay to measure serum HMGB1 and immunohistochemistry for tissue HMGB1 expression; and 4) reported or acquired relative risk estimates with 95\% confidence intervals (CIs) (or provided the data to calculate these). If the same data were published in studies of different languages, we only included the study with the largest number of cases. Exclusion criteria included: 1) use of the same population or an overlapping database; 2) the same study in a different language; and 3) use of cell culture or animal models (Figure 1).

\section{Data extraction}

Two authors (Wang and Qin) conducted independent data extraction, with disagreements resolved through discussion. The following data were extracted from each study: the first author's name, publication year, country where the study was implemented, sample size (cases and controls), and method of detection. Hazard ratio (HR) estimates with corresponding 95\% CIs for high vs low expression of HMGB1 was also extracted from relative articles. The study quality was assessed using the nine-star Newcastle-Ottawa Scale. ${ }^{40}$

\section{Statistical analysis}

Statistical heterogeneity among studies was evaluated using $I^{2}$ statistics. ${ }^{41}$ Mean differences with $95 \%$ CIs were calculated using a fixed or random effects model depending on heterogeneity. The random effects model was used when heterogeneity existed among studies $\left(I^{2}>25 \%\right)$, while the fixed effects model was used in the absence of statistical heterogeneity $\left(I^{2}<25 \%\right)$.

A meta-analysis was performed to compare HMGB1 protein expression levels between tissue and serum from ovarian cancer patients, those with benign tumors, and normal individuals. The multivariate HR was collected and the log 


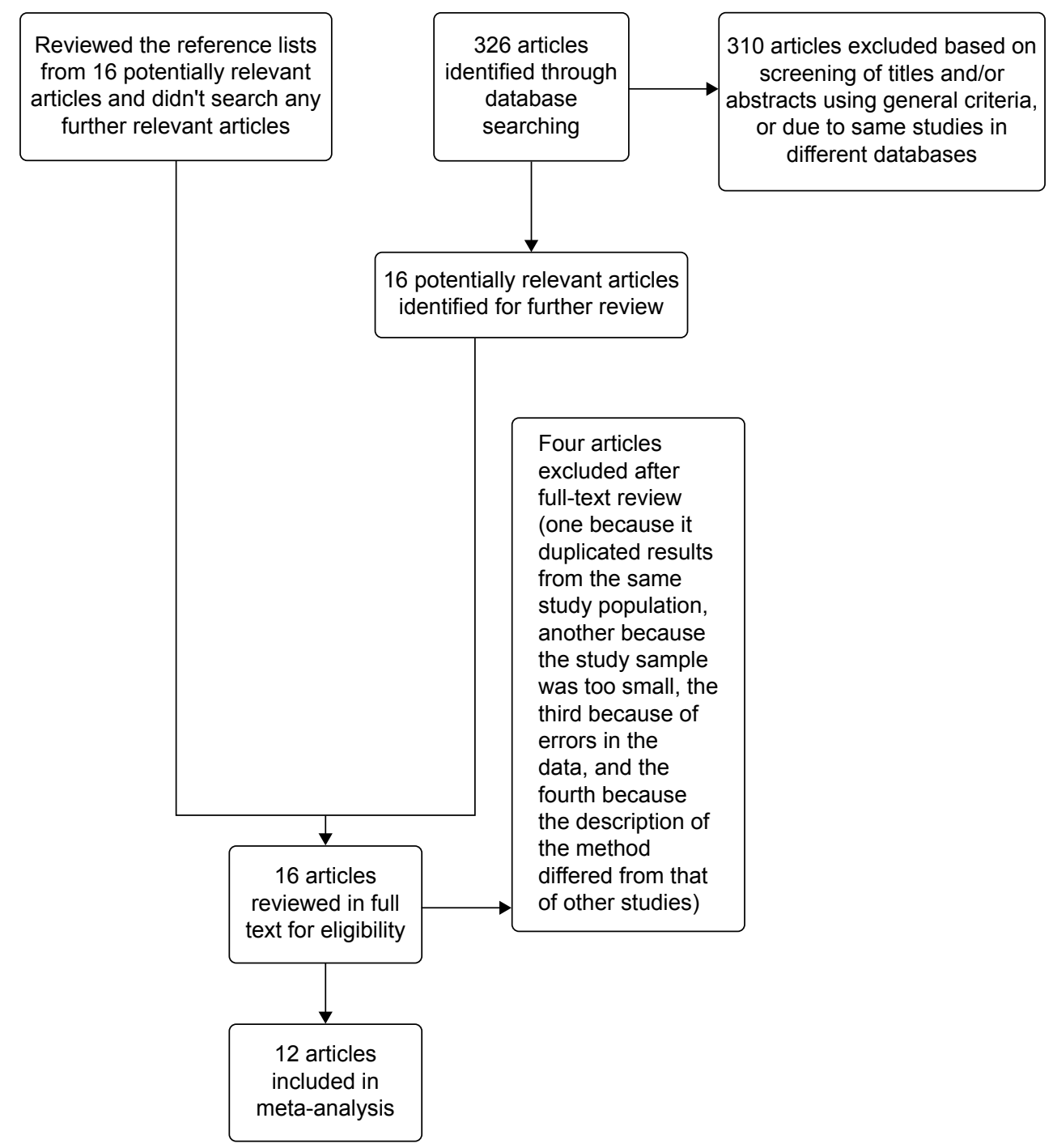

Figure I Flow diagram of the search and selection process of the studies.

HR and its standard errors were calculated for individual studies. The pooled HR with a 95\% CI was calculated for the association between HMGB1 expression and prognosis. Beggar's funnel plots and Egger's linear regression asymmetry test were used to detect publication bias. Sensitivity analysis was performed in which one study at a time was removed and the rest analyzed to evaluate whether the results were remarkably affected by a single study. $P<0.05$ was considered statistically significant. All analysis was performed using Review manager 5.3 and STATA 12.0 software.

\section{Results}

\section{Literature search}

Following the literature search and selection, a total of 12 studies $^{28-39}$ were included in the meta-analysis examining the association between HMGB1 tissue or serum overexpression with ovarian cancer. We identified seven potentially relevant articles concerning HMGB1 expression in tissue, four on HMGB1 expression in serum and one on HMGB1 expression in both serum and tissue. Four of 16 articles on HMGB1 expression in tissue were excluded: one because it duplicated results from the same study population, another because the study sample was too small, the third because of errors in the data, ${ }^{27}$ and the fourth because the description of the method differed from that of other studies. The characteristics of included studies are listed in Table 1.

\section{Study characteristics}

HMGB1 expression in ovarian cancer tissue was shown to be significantly higher than in normal ovarian tissue and benign tumor tissue. There was no evidence of heterogeneity among studies of HMGB1 positive expression in tissue $(P=0.32$, 
Table I Main characteristics of included studies

\begin{tabular}{|c|c|c|c|c|c|c|c|}
\hline \multirow[t]{2}{*}{ Study } & \multirow[t]{2}{*}{ Year } & \multirow[t]{2}{*}{ Country } & \multicolumn{3}{|c|}{ Sample size } & \multirow[t]{2}{*}{ Method } & \multirow{2}{*}{$\begin{array}{l}\text { Tissue or } \\
\text { serum }\end{array}$} \\
\hline & & & $\begin{array}{l}\text { Ovarian } \\
\text { tumor }\end{array}$ & $\begin{array}{l}\text { Benign ovarian } \\
\text { tumor }\end{array}$ & $\begin{array}{l}\text { Normal } \\
\text { control }\end{array}$ & & \\
\hline He et $\mathrm{al}^{32}$ & 2011 & $\begin{array}{l}\text { People's Republic } \\
\text { of China }\end{array}$ & 26 & 40 & 30 & $\begin{array}{l}\text { Immunohistochemistry } \\
\text { and ELISA }\end{array}$ & $\begin{array}{l}\text { Tissue and } \\
\text { serum }\end{array}$ \\
\hline Zhou et $\mathrm{al}^{29}$ & 2011 & $\begin{array}{l}\text { People's Republic } \\
\text { of China }\end{array}$ & 56 & 18 & 20 & Immunohistochemistry & Tissue \\
\hline Liu et $\mathrm{al}^{33}$ & 2011 & $\begin{array}{l}\text { People's Republic } \\
\text { of China }\end{array}$ & 56 & 24 & 20 & Immunohistochemistry & Tissue \\
\hline$W_{e i}^{31}$ & 2012 & $\begin{array}{l}\text { People's Republic } \\
\text { of China }\end{array}$ & 46 & 24 & 20 & Immunohistochemistry & Tissue \\
\hline Chen and Yuan ${ }^{30}$ & 2012 & $\begin{array}{l}\text { People's Republic } \\
\text { of China }\end{array}$ & 75 & Not mentioned & 40 & Immunohistochemistry & Tissue \\
\hline Xiao et $\mathrm{al}^{35}$ & 2014 & $\begin{array}{l}\text { People's Republic } \\
\text { of China }\end{array}$ & 55 & Not mentioned & 18 & Immunohistochemistry & Tissue \\
\hline Kong ${ }^{37}$ & 2014 & $\begin{array}{l}\text { People's Republic } \\
\text { of China }\end{array}$ & 32 & 79 & 45 & ELISA & Serum \\
\hline Zhi et $\mathrm{al}^{28}$ & 2014 & $\begin{array}{l}\text { People's Republic } \\
\text { of China }\end{array}$ & 40 & 60 & 30 & Immunohistochemistry & Tissue \\
\hline Li et $\mathrm{al}^{38}$ & 2014 & $\begin{array}{l}\text { People's Republic } \\
\text { of China }\end{array}$ & 105 & 46 & 33 & ELISA & Serum \\
\hline Li et $\mathrm{al}^{39}$ & 2014 & $\begin{array}{l}\text { People's Republic } \\
\text { of China }\end{array}$ & 47 & 30 & 30 & ELISA & Serum \\
\hline Zhi et $\mathrm{al}^{36}$ & 2014 & $\begin{array}{l}\text { People's Republic } \\
\text { of China }\end{array}$ & 40 & 60 & 30 & ELISA & Serum \\
\hline Paek et $\mathrm{al}^{34}$ & 2015 & $\begin{array}{l}\text { Republic of } \\
\text { Korea }\end{array}$ & 74 & Not mentioned & Not mentioned & Immunohistochemistry & Tissue \\
\hline
\end{tabular}

Abbreviation: ELISA, enzyme-linked immunosorbent assay.

$I^{2}=15 \%$ [ovarian cancer tissue vs normal tissue]; $P=0.62$, $I^{2}=0$ [ovarian cancer tissue vs benign tumor tissue]), but it was observed among studies of HMGB1 expression in serum $\left(P<0.00001, I^{2}=97 \%\right.$ [ovarian cancer patients vs normal patients]; $P<0.00001, I^{2}=97 \%$ [ovarian cancer patients vs benign tumor patients]). The pooled risk difference for ovarian cancer vs normal ovarian tissue was 0.64 with $95 \%$ CI: $0.57-0.70, Z=18.70, P<0.00001$, heterogeneity $P=15 \%$ (Figure 2A), and for ovarian cancer vs benign tumor tissue was 0.52 with $95 \%$ CI: $0.43-0.61, Z=11.14, P<0.00001$,

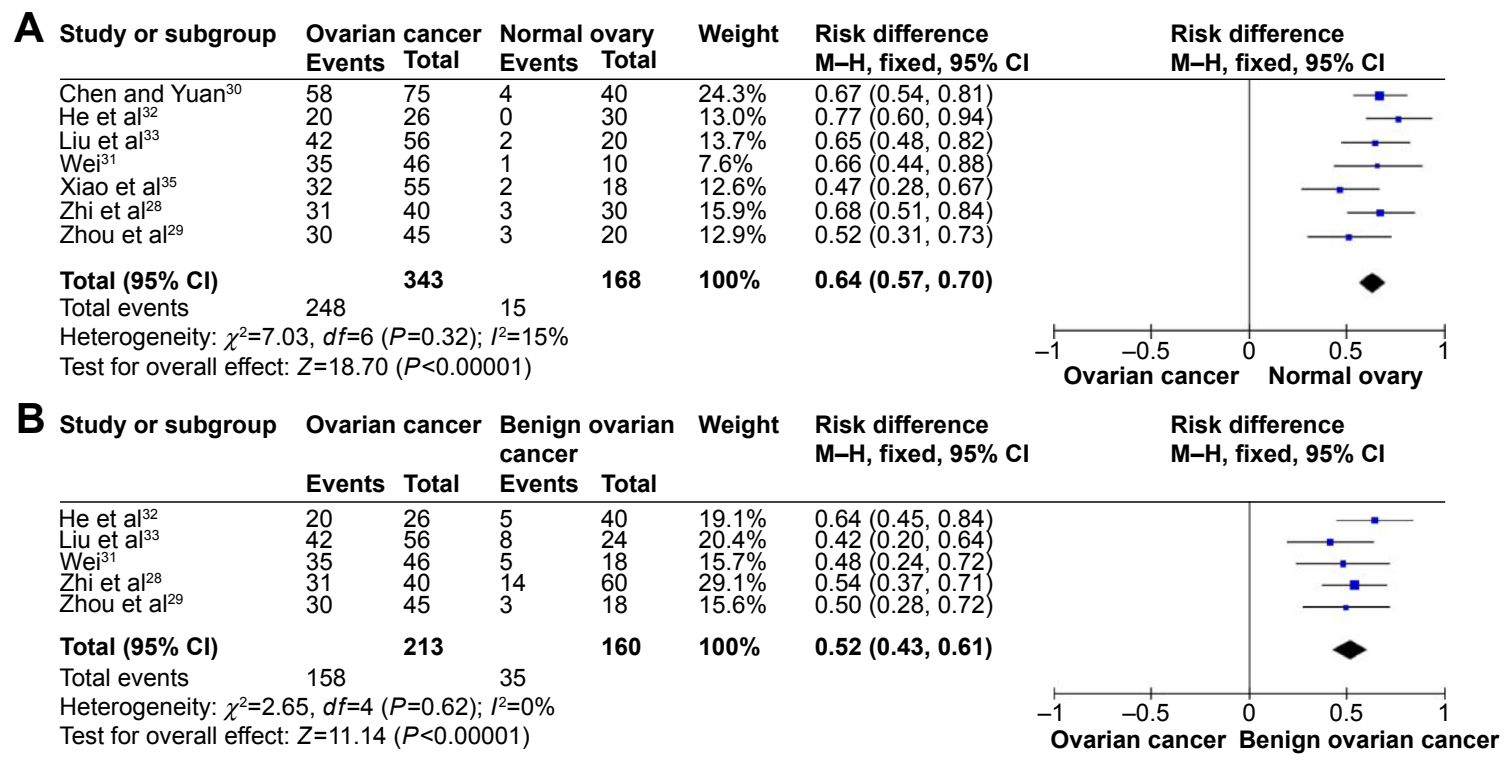

Figure 2 Forest plots for HMGBI in tissue with ovarian cancer and normal ovary (A) and for HMGBI in tissue with ovarian cancer and benign ovarian cancer (B). Abbreviations: $\mathrm{Cl}$, confidence interval; $\mathrm{M}-\mathrm{H}$, Mantel-Haenszel. 


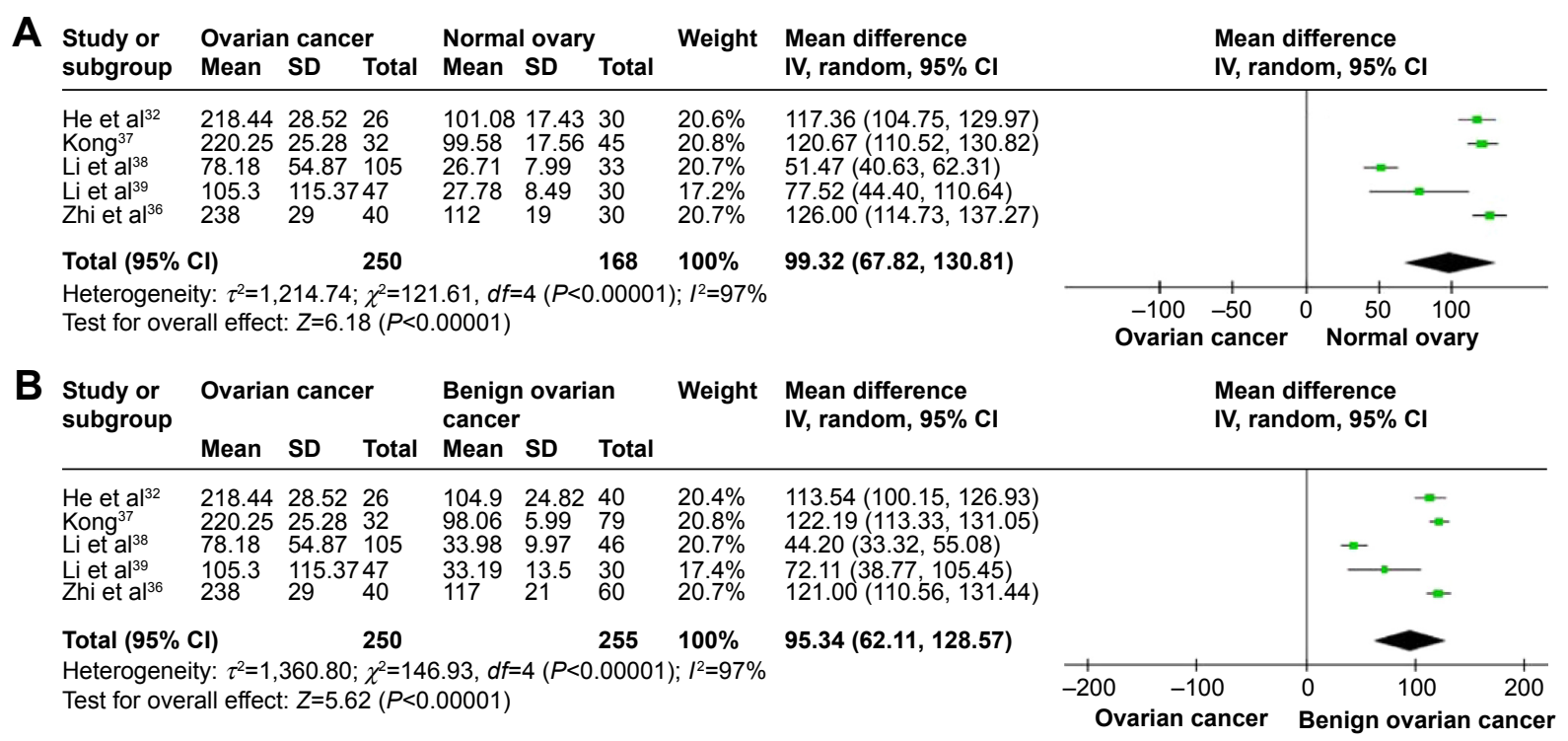

Figure 3 Forest plots for HMGBI in serum with ovarian cancer and normal ovary (A) and for HMGBI in serum with ovarian cancer and benign ovarian cancer (B). Abbreviations: $\mathrm{Cl}$, confidence interval; IV, inverse variance.

heterogeneity $I^{2}=0$ (Figure 2B). Similarly, HMGB1 protein levels in ovarian cancer patient serum were significantly higher than in serum from control individuals or those with benign tumors. The pooled mean difference was 99.32 with 95\% CI: 67.82-130.81, $Z=6.18, P<0.00001$, heterogeneity $I^{2}=97 \%$; 95.34 with $95 \%$ CI: $62.11-128.57, Z=5.62$, $P<0.0001$, heterogeneity $P^{2}=97 \%$ (Figure 3).

HRs showed that overall survival was significantly shorter in ovarian cancer patients with high HMGB1 expression compared with those with low HMGB1 expression. The pooled HR was 1.40 with $95 \%$ CI: $1.09-1.79, Z=2.66, P=0.008$, heterogeneity $l^{2}=50 \%$ (Figure 4).

\section{Sensitivity analysis and publication bias}

To explore heterogeneity among studies, we performed sensitivity analyses. The overall statistical significance was not found to change when any single study was omitted, indicating the stability of our analyses (Figure 5). There was also no publication bias in the positive association of HMGB1 levels with progression of ovarian cancer both in tissue $(P=0.881)$ and serum $(P=0.05)$ in this meta-analysis.

\section{Discussion}

The findings from this meta-analysis indicate that HMGB1 expression in both tissue and serum from ovarian cancer patients is higher than in those with benign tumors or normal controls. Moreover, the pooled HR of patients with high HMGB1 expression is increased by 1.40 -fold compared with those with low HMGB1 expression, suggesting that HMGB1 plays a crucial role in the pathogenesis of ovarian cancer. HMGB1 is a potential tissue and serum biomarker for ovarian cancer diagnosis, so the determination of HMGB1 levels in affected patients will help distinguish benign and malignant tumors and assess prognosis.

HMGB1 is a multifunctional factor that is functionally influenced by its subcellular location. It mainly exists in eukaryotic chromosomes in the cell nucleus, where it acts as a DNA chaperone to bind to minor grooves of DNA, stabilize nucleosides, and facilitate the assembly of site-specific DNA-binding proteins such as the nuclear hormone/nuclear hormone receptor complex. HMGB1 establishes proteinprotein interactions and enhances the activities of a number of transcription factors implicated in cancer development, including all class I steroid receptors, ${ }^{42} \mathrm{HOX},{ }^{43} \mathrm{P} 53, \mathrm{P} 73$,

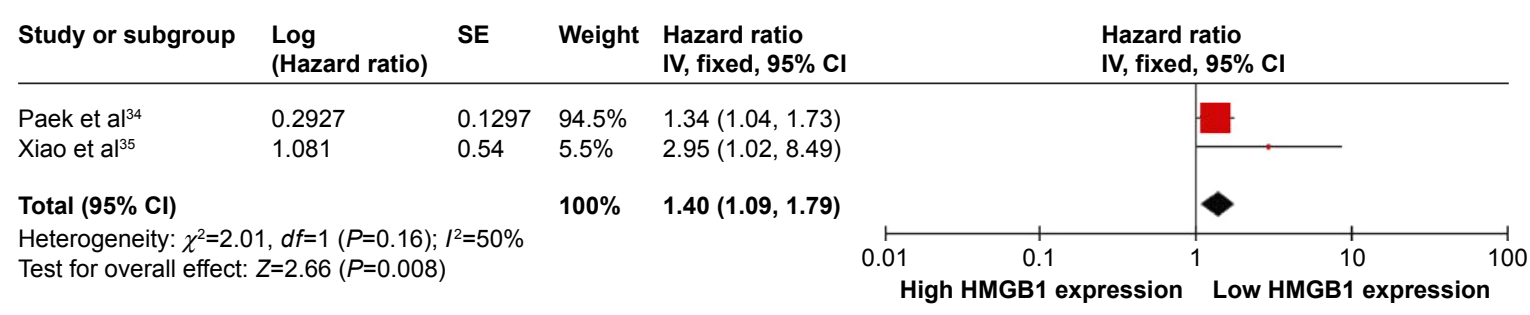

Figure 4 Forest plot for the association of HMGBI expression level and the risk of ovarian cancer.

Abbreviations: $\mathrm{Cl}$, confidence interval; IV, inverse variance; SE, standard error. 
A

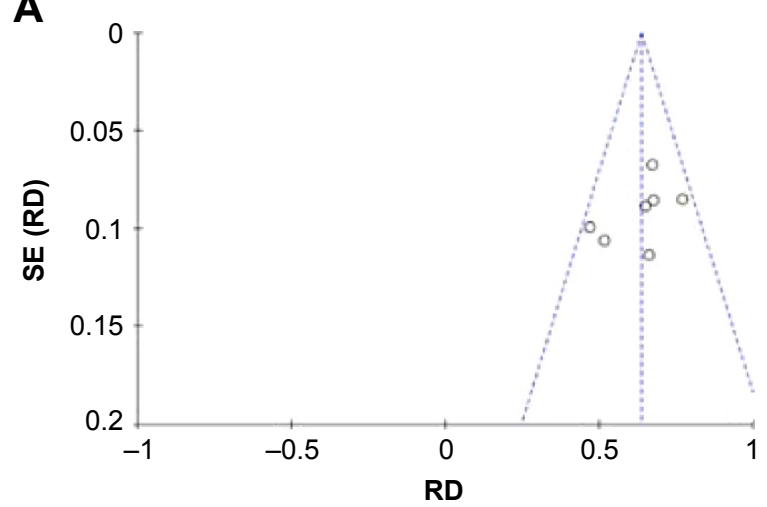

C

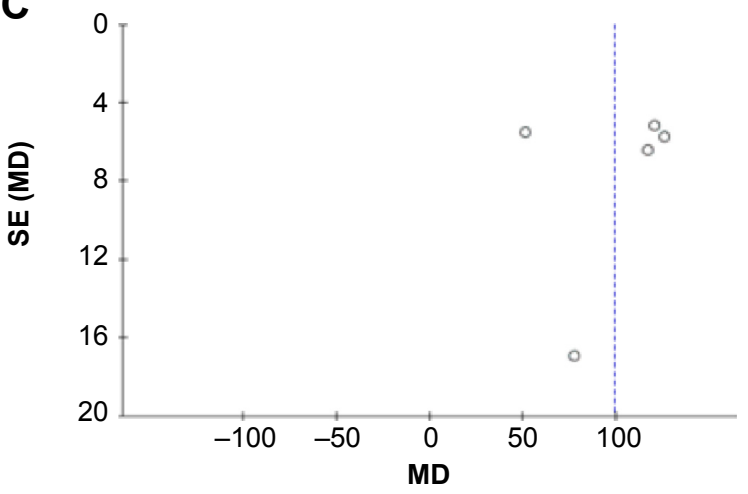

B

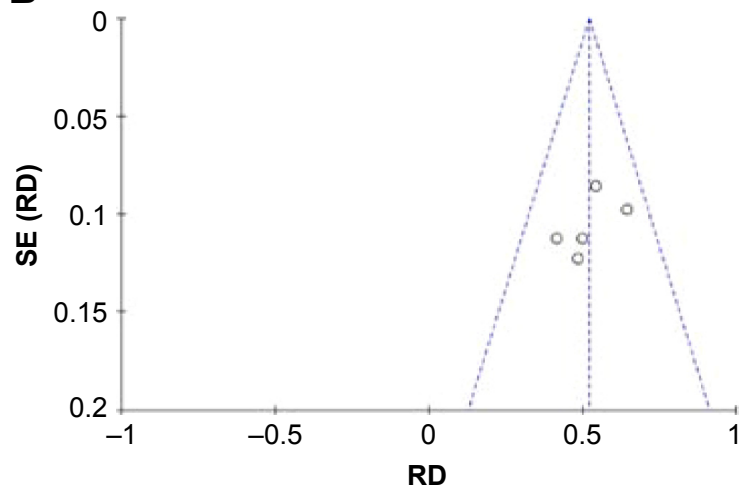

D

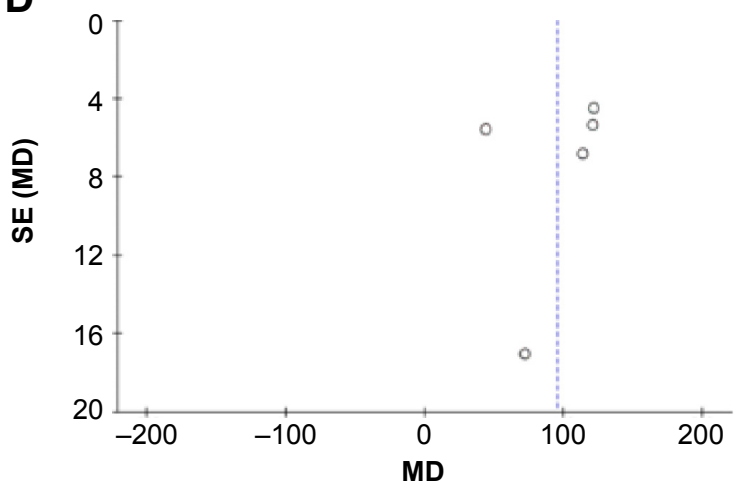

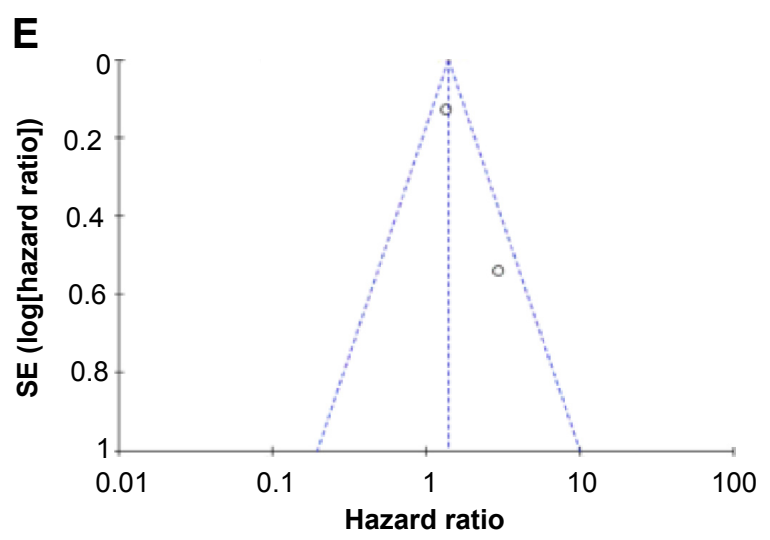

Figure 5 Funnel plots for publication bias.

Notes: $\mathrm{HMGBI}$ in tissue with ovarian cancer and normal ovary (A). HMGBI in tissue with ovarian cancer and benign ovarian cancer (B). HMGBI in serum with ovarian cancer and normal ovary (C). HMGBI in serum with ovarian cancer and benign ovarian cancer (D). The association of HMGBI expression level and the risk of ovarian cancer (E). Abbreviations: $M D$, mean difference; RD, risk difference; SE, standard error.

members of the Rel/nuclear factor (NF)- $\kappa B$ family, nuclear hormone receptors including estrogen receptor ${ }^{44}$ and retinoblastoma protein transcription complexes. ${ }^{45,46}$ In doing so, it regulates DNA structure, DNA repair, transcription, V(D)J recombination, differentiation, development, and extracellular signaling. ${ }^{47,48} \mathrm{HMGB} 1$ also regulates the transcription of many cancer genes, such as E-selectin, tumor necrosis factor- $\alpha$, insulin receptor, and BRCA1. ${ }^{49-51}$ Moreover, its binding to cell membrane receptors, including receptor for advanced glycation end products (RAGE), Toll-like receptors (TLRs: TLR2, TLR4, and TLR9), mitogen-activated protein kinase, NF- $\mathrm{KB}$, syndecan, and a specific receptor-tyrosine phosphatase, ${ }^{52}$ appears to be important in cancer progression ${ }^{44}$ and the coordination of immune system activation, cell migration, cell growth, angiogenesis, tissue repair, and regeneration. ${ }^{53}$ Krynetski et al ${ }^{54}$ previously suggested that HMGB1 plays a critical role in DNA repair through its involvement in the cytotoxic response to DNA modified by the incorporation of anticancer nucleoside analogs. HMGB1 also maintains genomic stability during tumor growth, ${ }^{55}$ and several malignancies, including gastric cancer, ${ }^{56}$ breast cancer, ${ }^{57}$ nasopharyngeal cancer, ${ }^{58}$ and squamous cell cancer of the head and neck ${ }^{59}$ are associated with HMGB1 overexpression. Indeed, a number of studies have reported 
that HMGB1 overexpression is crucial for ovarian cancer tumorigenesis, expansion, and invasion. ${ }^{39,60}$

New research has demonstrated that the function of HMGB1 extends beyond the nucleus, in an extracellular role in inflammation or cancer. Immune cells, including macrophages, mature dendritic cells, and natural killer cells release HMGB1 into the extracellular environment or serum by active and passive mechanisms in response to injury, infection, or other inflammatory stimuli. ${ }^{61,62} \mathrm{HMGB} 1$ can also be passively released into the extracellular space or serum following the unscheduled apoptosis of tumor cells, ${ }^{63}$ which is why it can be detected in the serum of cancer patients. ${ }^{64,65}$ Extracellular HMGB1 might contribute to cancer cell survival, proliferation, and the invasion of various cells. ${ }^{66,67}$ Thus, the evaluation of serum HMGB1 levels is essential for the diagnostic significance of HMGB1 in ovarian cancer and the inhibition of cancer progression by blocking serum HMGB1. Indeed, several studies have reported elevated serum HMGB1 levels in patients with various types of cancer. ${ }^{67,68}$

HMGB1 has a diverse range of functions in cancer, including anti-apoptosis, cell cycle progression, cell growth, invasion, migration, and metastasis. ${ }^{69,70}$ As it was described in previous study, ${ }^{71}$ malignant transformation and melanoma development were just caused by overexpression of HMGB1 in melanoma. Besides, HMGB1 played a crucial role in anti-apoptotic procession by leading to NF- $\kappa \mathrm{B}$ and c-IAP (inhibitor of apoptosis) that is a target gene product. ${ }^{72}$ These studies indicated that HMGB1 could promote tumor occurrence and development by functioning as an oncoprotein. Li et $\mathrm{al}^{38}$ found that ovarian cancer patient serum HMGB1 levels decreased significantly after they went into remission, while those with recurrence had higher serum HMGB1 levels compared with nonrecurrent patients, indicating that serum HMGB1 plays a key role in tumor progression. Cellular origin of serum HMGB1 should be carefully identified when we dignosed cancers, which is useful for improving the sensitivity of tumor diagnosis. However, the source of secreted HMGB1 was not easy to be discriminated from clinical patient's serum because it was hard to differentiate secreted HMGB1 between immune cells and cancer cells. As we know, HMGB1 can also secrete from immune cells, which might lead to elevation of serum HMGB1 in cancer of early stage.

According to Hanahan and Weinberg, tumors can be characterized by six properties: unlimited replicative potential, angiogenesis, evasion of apoptosis, self-sufficiency in growth signals, insensitivity to inhibitors of growth, and tissue invasion and metastasis. A seventh property is suggested to be inflammation. ${ }^{73}$ Most cancer deaths are caused by tumor invasion and metastasis rather than by the primary tumor itself. Previous studies found that tissue or serum HMGB1 expression is associated with poor prognosis in a variety of cancers, including laryngeal squamous cell carcinoma, ${ }^{74}$ gastric cancer, ${ }^{75}$ pancreatic cancer, ${ }^{76}$ colorectal cancer, ${ }^{77}$ and cervical cancer. ${ }^{78}$ Huttunen ${ }^{79}$ previously showed that the suppression of RAGE and HMGB1 by antisense S-oligodeoxynucleotide or HMGB1 150-183 peptide (RAGE-binding motif) inhibits the growth, migration, and invasion in cancer cells in vitro. This indicated that HMGB1RAGE signaling plays a key role in tumor invasion and metastasis, leading to the observed poor prognosis.

Several studies also demonstrated a positive correlation between HMGB1 serological activity and the progression of ovarian cancer. ${ }^{34,35}$ Our meta-analysis was in agreement with this, finding that serum HMGB1 levels were connected with poor prognosis. Pooled HR was shown to be increased by 1.40 -fold in ovarian cancer patients with high HMGB1 expression compared with those with low HMGB1 expression, suggesting that high HMGB1 expression is significantly associated with patient mortality. Additionally, serum HMGB1 levels in patients with stages III-IV cancer were significantly higher than in those with stages I-II cancer, as well as in those ovarian cancer tissues with lymph node metastasis compared with those without. Thus, serum HMGB1 levels were inversely correlated with overall survival in patients with far-advanced stage or lymph node metastasis, suggesting that they could be a potential prognostic factor for ovarian cancer patients. HMGB1 may also serve as a therapeutic target, because $H M G B 1$ knockdown was able to inhibit ovarian cancer growth and metastasis.

\section{Conclusion}

This meta-analysis demonstrated that HMGB1 is more highly expressed in the tissue and serum of ovarian cancer patients compared with controls and those with benign tumors, and that the increased serum levels may contribute to aggressive tumor progression. HMGB1 is also significantly associated with the prognosis of patients with ovarian cancer. Therefore, the early detection of elevated HMGB1 serum levels may help clinicians offer therapeutic strategies to improve the survival of ovarian cancer patients.

\section{Acknowledgments}

This work was supported by the Natural Science Foundation of Shandong Province, People's Republic of China (ZR2009CM138); the Medicine Health, Science and Technology Development Program of Shandong Province, 
People's Republic of China (2011HW069), and the Science and Technology Development Plan Project of Shandong Province, People's Republic of China (2013GSF11834).

\section{Disclosure}

The authors report no conflicts of interest in this work.

\section{References}

1. Siegel RL, Miller KD, Jemal A. Cancer statistics, 2015. CA Cancer J Clin. 2015;65(1):5-29.

2. Hennessy BT, Coleman RL, Markman M. Ovarian cancer. Lancet. 2009; 374(9698):1371-1382.

3. Torre LA, Bray F, Siegel RL, Ferlay J, Lortet-Tieulent J, Jemal A. Global cancer statistics, 2012. CA Cancer J Clin. 2015;65(2):87-108.

4. Cho KR, Shih IeM. Ovarian cancer. Annu Rev Pathol. 2009;4:287-313.

5. Bast Jr RC, Hennessy B, Mills GB. The biology of ovarian cancer: new opportunities for translation. Nat Rev Cancer. 2009;9:415-428.

6. Chaffer CL, Weinberg RA. A perspective on cancer cell metastasis. Science. 2011;331:1559-1564.

7. Walker JM, Goodwin GH, Johns EW, Wietzes P, Gaastra W. A comparison of the amino-terminal sequences of two calf-thymus chromatin nonhistone proteins. Int J Pept Protein Res. 1977;9:220-223.

8. Muller S, Bianchi ME, Knapp S. Thermodynamics of HMGB1 interaction with duplex DNA. Biochemistry. 2001;40:10254-10261.

9. Strichman-Almashanu LZ, Bustin M, Landsman D. Retroposed copies of the HMG genes: a window to genome dynamics. Genome Res. 2003;13: $800-812$.

10. Agresti A, Scaffidi P, Riva A, Caiolfa VR, Bianchi ME. GR and HMGB1 interact only within chromatin and influence each other's residence time. Mol Cell. 2005;18:109-121.

11. Jang A, Liew H, Kim YM, et al. p35 deficiency accelerates HMGB-1mediated neuronal death in the early stages of an Alzheimer's disease mouse model. Curr Alzheimer Res. 2013;10(8):829-843.

12. Park SY, Lee SW, Kim HY, Lee WS, Hong KW, Kim CD. HMGB1 induces angiogenesis in rheumatoid arthritis via HIF-1 $\alpha$ activation. Eur J Immunol. 2015;45(4):1216-1227.

13. Park S, Yoon SJ, Tae HJ, Shim CY. RAGE and cardiovascular disease. Front Biosci. 2011;16:486-497.

14. Qin WD, Mi SH, Li C, et al. Low shear stress induced HMGB1 translocation and release via PECAM-1/PARP-1 pathway to induce inflammation response. PLoS One. 2015;10(3):e120586.

15. Singh A, Feng Y, Mahato N, Li J, Wu C, Gong J. Role of high-mobility group box 1 in patients with acute obstructive suppurative cholangitisinduced sepsis. J Inflamm Res. 2015;8:71-77.

16. Lee H, Song M, Shin N, et al. Diagnostic significance of serum HMGB1 in colorectal carcinomas. PLoS One. 2012;7(4):e34318.

17. Ueda M, Takahashi Y, Shinden Y, et al. Prognostic significance of high mobility group box 1 (HMGB1) expression in patients with colorectal cancer. Anticancer Res. 2014;34(10):5357-5362.

18. Suren D, Yildirim M, Demirpence O, et al. The role of high mobility group box 1 (HMGB1) in colorectal cancer. Med Sci Monit. 2014;20: 530-537.

19. Huang QX, Wang GB, Sun NF, Wang CY. Inhibitory effects of high mobility group box 1 antisense nucleotide on invasion of human pancreatic cancer cell line PCNA-1. Ai Zheng. 2004;23(9):1036-1040.

20. Mardente S, Mari E, Consorti F, et al. HMGB1 induces the overexpression of miR-222 and miR-221 and increases growth and motility in papillary thyroid cancer cells. Oncol Rep. 2012;28(6):2285-2289.

21. Liu Y, Zhang P, Wu Z, et al. Screening of highly-expressed-HMGB1gene human lung cancer cell lines. Zhong Guo Fei Ai Za Zhi. 2009;12(9): 965-968.

22. Cheng $P$, Dai W, Wang F, et al. Ethyl pyruvate inhibits proliferation and induces apoptosis of hepatocellular carcinoma via regulation of the HMGB1-RAGE, and AKT pathways. Biochem Biophys Res Commun. 2014;443(4):1162-1168.
23. Dong YD, Cui L, Peng CH, Cheng DF, Han BS, Huang F. Expression and clinical significance of HMGB1 in human liver cancer: knockdown inhibits tumor growth and metastasis in vitro and in vivo. Oncol Rep. 2013;29(1):87-94.

24. Sheng XG, Du XL, Zhang X, et al. Clinical value of serum HMGB1 levels in early detection of recurrent squamous cell carcinoma of uterine cervix: comparison with serum SCCA, CYFRA21-1, and CEA levels. Croat Med J. 2009;50(5):455-464.

25. Akaike H, Kono K, Sugai H, et al. Expression of high mobility group box chromosomal protein-1 (HMGB-1) in gastric cancer. Anticancer Res. 2007;27(1A):449-457.

26. Meng Q, Zhao J, Liu H, et al. HMGB1 promotes cellular proliferation and invasion, suppresses cellular apoptosis in osteosarcoma. Tumor Biol. 2014;35(12):12265-12274.

27. Machado L, Moseley PM, Moss R, et al. High-mobility group protein 1 (HMGB1) is an independent predictor of poor survival in ovarian cancer. Immunology. 2014;143:83.

28. Zhi H, Ma HY, Qu RH, et al. Expression and clinical significance of HMGBl in ovarian carcinoma. Hebei Med J. 2014;(10):1461-1463.

29. Zhou CX, Wu JJ, Yu Q, et al. Significance of expression of HMGB1 and Smac/DIABLO protein in epithelial ovarian cancer. J Chin Phys. 2011;13(11):1455-1458, 1463.

30. Chen XY, Yuan R. Expression and significance of HMGB1 and E-cadherin in ovarian carcinoma. J Chongqing Med Univ. 2012;37(7): 614-617.

31. Wei SP. Expression and significance of HMGB1 in human ovarian cancer. Chin J Aesthetic Med. 2012;21(18):65-66.

32. He XY, Wang HL, Chen XH, et al. Expression and clinical significance of HMGB1 in ovarian carcinoma. Prog Modern Biomed. 2011;11(4): 695-697.

33. Liu XY, Zhang J, Chen J. Expression and clinical significance of high mobility group box in ovarian cancer tissues and monoclonal cell subclones. J Shandong Univ (Health Sciences). 2011;12:123-127+131.

34. Paek J, Lee M, Nam EJ, Kim SW, Kim YT. Clinical impact of high mobility group box 1 protein in epithelial ovarian cancer. Arch Gynecol Obstet. Epub 2015 Aug 25.

35. Xiao HT, Zhang WQ, Liu WX, et al. The prognostic and chemosensitive value of HMGB 1 in epithelial ovarian cancer patients. Prog Obst Gynecol. 2014;(10):783-786.

36. Zhi H, Ma HY, Chen XL; Center for Disease Control and Prevention of Qiaoxi District. The changes and clinical significance of serum levels of HMGB1, VEGF before and after operation in patients with ovarian carcinoma. Hebei Med J. 2014;(9):1297-1299.

37. Kong SJ. HMGB1 associated HE4 and CA125 in the diagnosis of early ovarian epithelial sex. Qingdao Univ. 2014;D:1-40.

38. Li Y, Tian J, Fu X, Chen Y, Zhang W, Yao H. Serum high mobility group box protein 1 as a clinical marker for ovarian cancer. Neoplasma. 2014; 61(5):579-584.

39. Li YC, Tian J, Yao HR, et al. High-mobility group protein B1 (HMGB1) and its potential in diagnosis and treatment of ovarian cancer. Chin J Clin Oncol. 2014;(7):425-429.

40. Wells GA, Shea B, O'Connell D, et al. The Newcastle Ottawa Scale (NOS) for assessing the quality of nonrandomized studies in metaanalyses. Ottawa, Canada: Dept of Epidemiology and Community Medicine, University of Ottawa. http://www.ohri.ca/programs/ clinical_epidemiology/oxford.htm. Accessed February 10, 2010.

41. Higgins JP, Thompson SG. Quantifying heterogeneity in a meta-analysis. Stat Med. 2002;21(11):1539-1558.

42. Boonyaratanakornkit $V$, Melvin V, Prendergast $P$, et al. High-mobility group chromatin proteins 1 and 2 functionally interact with steroid hormone receptors to enhance their DNA binding in vitro and transcriptional activity in mammalian cells. Mol Cell Biol. 1998;18:4471-4487.

43. Zappavigna V, Falciola L, Helmer-Citterich M, Mavilio F, Bianchi ME. HMG1 interacts with HOX proteins and enhances their DNA binding and transcriptional activation. EMBO J. 1996;15:4981-4991.

44. Tang D, Kang R, Zeh HR, Lotze MT. High-mobility group box 1 and cancer. Biochim Biophys Acta. 2010;1799:131-140. 
45. Brezniceanu ML, Volp K, Bosser S, et al. HMGB1 inhibits cell death in yeast and mammalian cells and is abundantly expressed in human breast carcinoma. FASEB J. 2003;17:1295-1297.

46. Thomas JO, Travers AA. HMG1 and 2, and related 'architectural' DNA binding proteins. Trends Biochem Sci. 2001;26:167-174.

47. Czura CJ, Wang H, Tracey KJ. Dual roles for HMGB1: DNA binding and cytokine. J Endotoxin Res. 2001;7:315-321.

48. Wang $\mathrm{H}$, Bloom $\mathrm{O}$, Zhang $\mathrm{M}$, et al. HMG-1 as a late mediator of endotoxin lethality in mice. Science. 1999;285:248-251.

49. Thanos D, Maniatis T. The high mobility group protein HMG I(Y) is required for NF-kappa B-dependent virus induction of the human IFN-beta gene. Cell. 1992;71:777-789.

50. Baldassarre G, Battista S, Belletti B, et al. Negative regulation of BRCA1 gene expression by HMGA1 proteins accounts for the reduced BRCA1 protein levels in sporadic breast carcinoma. Mol Cell Biol. 2003;23: 2225-2238.

51. Fashena SJ, Reeves R, Ruddle NH. A poly(dA-dT) upstream activatingsequence binds high-mobility group I protein and contributes to lymphotoxin(tumor necrosis factor-beta) gene regulation. Mol Cell Biol. 1992;12:894-903.

52. Ulloa L, Messmer D. High-mobility group box 1 (HMGB1) protein: Friend and foe. Cytokine Growth Factor Rev. 2006;17:189-201.

53. Taguchi A, Blood DC, del Toro G, et al. Blockade of RAGE-amphoterin signalling suppresses tumor growth and metastases. Nature. 2000; 405:354-360.

54. Krynetski EY, Krynetskaia NF, Bianchi ME, Evans WE. A nuclear protein complex containing high mobility group proteins B1 and B2, heat shock cognate protein 70, ERp60, and glyceraldehyde-3-phosphate dehydrogenase is involved in the cytotoxic response to DNA modified by incorporation of anticancer. Cancer Res. 2003;63(1):100-106.

55. Kang R, Zhang Q, Zeh HJ, Lotze MT, Tang D. HMGB1 in cancer: good, bad, or both? Clin Cancer Res. 2013;19(15):4046-4057.

56. Brezniceanu ML, Volp K, Bosser S, et al. HMGB1 inhibits cell death in yeast and mammalian cells and is abundantly expressed in human breast carcinoma. FASEB J. 2003;17:1295-1297.

57. Akaike H, Kono K, Sugai H, et al. Expression of high mobility group box chromosomal protein-1 (HMGB-1) in gastric cancer. Anticancer Res. 2007;27:449-457.

58. Wu D, Ding Y, Wang S, Zhang Q, Liu L. Increased expression of high mobility group box 1 (HMGB1) is associated with progression and poor prognosis in human nasopharyngeal carcinoma. J Pathol. 2008;216: 167-175.

59. Liu Y, Xie C, Zhang X, et al. Elevated expression of HMGB1 in squamous-cell carcinoma of the head and neck and its clinical significance. Eur J Cancer. 2010;46:3007-3015.

60. Chen J, Liu X, Zhang J, Zhao Y. Targeting HMGB1 inhibits ovarian cancer growth and metastasis by lentivirus-mediated RNA interference. J Cell Physiol. 2012;227(11):3629-3638.

61. Bonaldi T, Talamo F, Scaffidi P, et al. Monocytic cells hyperacetylate chromatin protein HMGB1 to redirect it towards secretion. EMBO J. 2003;22:5551-5560.

62. Semino C, Angelini G, Poggi A, Rubartelli A. NK/iDC interaction results in IL-18 secretion by DCs at the synaptic cleft followed by NK cell activation and release of the DC maturation factor HMGB1. Blood. 2005; 106:609-616.
63. Zeh HJ, Lotze MT. Addicted to death: invasive cancer and the immune response to unscheduled cell death. J Immunother. 2005;28:1-9.

64. Palumbo R, Sampaolesi M, De Marchis F, et al. Extracellular HMGB1, a signal of tissue damage, induces mesoangioblast migration and proliferation. J Cell Biol. 2004;164:441-449.

65. Cheng BQ, Jia CQ, Liu CT, et al. Serum high mobility group box chromosomal protein 1 is associated with clinicopathologic features in patients with hepatocellular carcinoma. Dig Liver Dis. 2008;40: 446-452.

66. Parkkinen J, Raulo E, Merenmies J, Nolo R, et al. Amphoterin, the 30-kDa protein in a family of HMG1-type polypeptides. Enhanced expression in transformed cells, leading edge localization, and interactions with plasminogen activation. J Biol Chem. 1993;268:19726-19738.

67. Chung HW, Lee SG, Kim H, et al. Serum high mobility group box-1 (HMGB1) is closely associated with the clinical and pathologic features of gastric cancer. J Transl Med. 2009;7:38.

68. Sheng XG, Du XL, Zhang X, et al. Clinical value of serum HMGB1 levels in early detection of recurrent squamous cell carcinoma of uterine cervix: comparison with serum SCCA, CYFRA21-1, and CEA levels. Croat Med J. 2009;50:455-464.

69. Ellerman JE, Brown CK, de Vera M, et al. Masquerader: high mobility group box-1 and cancer. Clin Cancer Res. 2007;13:2836-2848.

70. Evans A, Lennard TW, Davies BR. High-mobility group protein 1(Y): metastasis-associated or metastasis-inducing? J Surg Oncol. 2004;88: 86-99.

71. Poser I, Golob M, Buettner R, Bosserhoff AK. Upregulation of HMG1 leads to melanoma inhibitory activity expression in malignant melanoma cells and contributes to their malignancy phenotype. Mol Cell Biol. 2003;23:2991-2998

72. Volp K, Brezniceanu ML, Bosser S, et al. Increased expression of high mobility group box 1 (HMGB1) is associated with an elevated level of the antiapoptotic c-IAP2 protein in human colon carcinomas. Gut. 2006;55:234-242.

73. Hanahan D, Weinberg RA. The hallmarks of cancer. Cell. 2000;100: 57-70.

74. Qiu G, Li Y, Liu Z, Wang M, Ge Y, Bai X. Clinical value of serum HMGB1 in diagnosis and prognosis of laryngeal squamous cell carcinoma. Med Oncol. 2014;31(12):316.

75. Chung HW, Lee SG, Kim H, et al. Serum high mobility group box-1 (HMGB1) is closely associated with the clinical and pathologic features of gastric cancer. J Transl Med. 2009;7:38.

76. Chung HW, Lim JB, Jang S, Lee KJ, Park KH, Song SY. Serum high mobility group box-1 is a powerful diagnostic and prognostic biomarker for pancreatic ductal adenocarcinoma. Cancer Sci. 2012;103(9): 1714-1721.

77. Yao X, Zhao G, Yang H, Hong X, Bie L, Liu G. Overexpression of highmobility group box 1 correlates with tumor progression and poor prognosis in human colorectal carcinoma. J Cancer Res Clin Oncol. 2010; 136(5):677-684.

78. Pang X, Zhang Y, Wei H, et al. Expression and effects of high-mobility group box 1 in cervical cancer. Int J Mol Sci. 2014;15(5):8699-8712.

79. Huttunen HJ, Fages C, Kuja-Panula J, Ridley AJ, Rauvala H. Receptor for advanced glycation end products-binding $\mathrm{COOH}$-terminal motif of amphoterin inhibits invasive migration and metastasis. Cancer Res. 2002;62:4805-4811.
OncoTargets and Therapy

\section{Publish your work in this journal}

OncoTargets and Therapy is an international, peer-reviewed, open access journal focusing on the pathological basis of all cancers, potential targets for therapy and treatment protocols employed to improve the management of cancer patients. The journal also focuses on the impact of management programs and new therapeutic agents and protocols on

\section{Dovepress}

patient perspectives such as quality of life, adherence and satisfaction. The manuscript management system is completely online and includes a very quick and fair peer-review system, which is all easy to use. Visit http://www.dovepress.com/testimonials.php to read real quotes from published authors. 